\title{
ニース条約による $\mathrm{EU}$ 主要機関及び政策決定の改革
}

\section{熟 江 義 勝}

\section{はじめに}

ニース条約は，アムステルダム条約で「積み残された課題」を解決し，27カ 国から成る EUを目指す条約である。2000年12月にフランスのニース欧州理 事会で合意され，2001年 2 月26日に，EUの既存の15の加盟国によって調印さ れた後, 現在, 各加盟国において批准作業中である。2001年 6 月に開催された イェーテボリ欧州理事会では，現在の加盟国による2002年末までの批准作業の 完了と2004年までの中東欧への第 1 次拡大の実現が確認されている。

本稿は，ニース条約による改定の中でも特に，欧州議会，理事会，欧州委員 会及び政策決定過程に関する改革について分析をおこなう。主な改革点として は，欧州議会に関しては，27カ国への拡大に備えた既存の加盟国を含めた全体 的な議席配分の見直しが行われている。欧州委員会に関しては，任命過程の改 革, 委員長の指導力の強化及び全体の定員の見直しを含む加盟国への委員の配 分方式の改定が行われている。理事会に関しては，新規加盟国を含めた加盟国 の加重票数の全面的見直しとそれに伴う特定多数決の可決に必要な票数の改定 及び可決要件の改定が行われている。政策決定に関しては，理事会における特 定多数決や共同決定手続きの適用分野の拡大が行われている。また，今回の改 定では，27カ国体制の $\mathrm{EU}$ を前提としつつも，新規加盟予定の国家のうちど 
『日本 $\mathrm{EU}$ 学会年報』第 22 号, 平成 14 年 9 月

の国がいつ加盟するのかが依然として未確定のため，改定内容の発効日までに， 新規加盟国が全くなかった場合の既存の15の加盟国のみの場合，あるいは12の 加盟予定の国家のうちの数力国のみの加盟が実現した場合, そして, 中東欧の 全ての加盟予定国の加盟が完了した場合等，いくつかの過渡期的な対応策を詳 細に規定していることが特徴として挙げられる。そのため, 既存の15力国体制 の $\mathrm{EU}$ に関する改定は，ニース条約本文に規定されているものの，加盟国の 数に応じて変動する多段階の対応は，ニース条約の付属議定書である「欧州同 盟の拡大に関する議定書」をはじめとする付属議定書あるいは宣言に規定され ている。以下では，それぞれの機関あるいは政策決定過程に関する改革点とそ の特徴あるいは問題点を分析することにしたい。

\section{1 欧州議会}

\section{1 欧州議会議席数の上限の再設定}

欧州議会の議員数は，ECSC の創設以来，一貫して増加の一途を辿ってき た。これは，1981年のギリシャの加盟の際の全体的な議席数の見直しに伴う議 席総数の大幅な増加及びドイツ統一に伴うドイッの人口の増加への対応として の全体的な議席配分数の見直し，ざらには，新規加盟国に対する新たな議席の 配分の結果であった。そのため，1958年には142であった議席数は，現在626議 席まで増加している。現行の議席配分方式のまま，12力国にも及ぶ新規加盟国 が加盟すれば，欧州議会の議席は1000名を越えることになる。この無制限の議 席数の増大は，欧州議会の議会としての有効性を劦かすものとなりかねない。 そのため，アムステルダム条約では，欧州議会の議員総数を700以下とする条 約改正が行われたのである。しかしながら，アムステルダム条約では，既存の 加盟国及び新規加盟予定国の具体的な議席数の改定は, 明確にされていなかっ た。そのため，今回のニース条約による改定では，欧州議会の総議員数の上限 を732議席に変更するだけでなく（EC 条約189条 2 段），ニース条約に附属する 
「欧州同盟の拡大に関する議定書」2条によって，既存の加盟国に対する議席の 再配分及び12の新規加盟国への配分予定議席を規定している。ただ，ニース 条約では, 15力国, 16力国から26力国，27カ国の3 段階に分けた状況を想定し ているため，以下でも 3 つの場合に分けて分析を行う（以下表 1 を参照された w)。

\section{2 議席の再配分}

\section{(1) 15 力国体制の場合}

既存の加盟国に対する議席の再配分の特徵は, 新たに設定された議席の上限 との関係で, 既存の加盟国の議席が大幅に削減されていることである。全体で は, 現行の議席が約 $69 \%$ ま゙削減され, 既存の加盟15力国の総議席は, 現在の 626から430議席に減少する予定である。ただし，縮小率は一律ではなく，最大 の議席を有するドイツと最小の議席配分を受けているルクセンブルグは現行の ままで，その他の全ての加盟国の議席が縮小再配分されている。また，議席が 縮小配分された加盟国の中でもポルトガル，ギリシャ及びベルギーが現行議席 の88\%を確保したのに対して，スペインの約78\%，アイルランドの80\%，オラ ンダ，オーストリア，デンマーク及びフィンランドの約 $81 \%$ ど加盟国によっ て縮小率がかなり異なるものとなっている。

（2）27カ国体制の場合

新規加盟を予定する12の加盟国に配分される議席の合計は302議席であり， 既存の加盟国の総議席（430議席）と併せた27カ国の総議席は，732議席となる。 新規加盟国への議席配分に関しては，一部の新規加盟国に対する不利な扱いが 顕著である。例えば，人口 1000 万人弱のポルトガルが 22 議席を配分されている のに対して，ポルトガルより人口の多いチェコやハンガリーに対しては，20議 席が配分されているにすぎない。また，ルクセンブルグには，3倍以上の人口 を有するエストニアと同じ 6 議席が配分されているのに対して，ルクセンブル グと 5 万人の人口差しかないマル夕に対しては 5 議席しか配分されていない。 
『日本 $\mathrm{EU}$ 学会年報』第 22 号, 平成14年 9 月

表 1 理事会の加重票数, 欧州議会の議席及び欧州委員会の構成員数 15力国（1995年時点）

\begin{tabular}{|c|c|c|c|c|c|c|c|c|c|}
\hline 名 & 人口 & 人口\% & 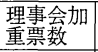 & 票数\% & 人口/票数 & \begin{tabular}{|l} 
欧州議会 \\
\end{tabular} & 議席\% & 人口/議席 & 欧州委員 \\
\hline ツ & 8,166 & 21.9 & 10 & 11.5 & 817 & 99 & 16 & 825 & 2 \\
\hline イ 夕 リ ア & 5,729 & 15.4 & 10 & 11.5 & 573 & 87 & 14 & 659 & 2 \\
\hline イギリ ス & 5,861 & 15.8 & 10 & 11.5 & 586 & 87 & 14 & 674 & 2 \\
\hline フ ラ ン ス & 5,814 & 15.6 & 10 & 11.5 & 581 & 87 & 14 & 668 & 2 \\
\hline ス ペ イ ン & 3,921 & 10.5 & 8 & 9.2 & 490 & 64 & 10 & 613 & 2 \\
\hline オ ラ ン ダ & 1,546 & 4.2 & 5 & 5.7 & 309 & 31 & 5 & 499 & 1 \\
\hline ポルトガル & 992 & 2.7 & 5 & 5.7 & 198 & 25 & 4 & 397 & 1 \\
\hline ギリ シ ヤ & 1,045 & 2.8 & 5 & 5.7 & 209 & 25 & 4 & 418 & 1 \\
\hline ベ ル ギー & 1,014 & 2.7 & 5 & 5.7 & 203 & 25 & 4 & 406 & 1 \\
\hline スウェーデン & 883 & 2.4 & 4 & 4.6 & 221 & 22 & 4 & 401 & 1 \\
\hline オーストリア & 805 & 2.2 & 4 & 4.6 & 201 & 21 & 3 & 383 & 1 \\
\hline デンマーク & 523 & 1.4 & 3 & 3.4 & 174 & 16 & 3 & 327 & 1 \\
\hline フィンランド & 511 & 1.4 & 3 & 3.4 & 170 & 16 & 3 & 319 & 1 \\
\hline アイルランド & 360 & 1.0 & 3 & 3.4 & 120 & 15 & 2 & 240 & 1 \\
\hline ルクセンブルグ & 41 & 0.1 & 2 & 2.3 & 21 & 6 & 1 & 68 & 1 \\
\hline 計 & 37,211 & 100 & 87 & 100 & 428 & 626 & 100 & 594 & 20 \\
\hline 可 決 多 数 & & & 62 & 71.3 & & & & & \\
\hline 否 決 多 数 & & & 26 & 29.9 & & & & & \\
\hline
\end{tabular}

15力国（2005年1月 1 日以降，但し欧州議会に関しては2004年以降）

\begin{tabular}{|c|c|c|c|c|c|c|c|c|c|c|c|}
\hline 名 & 人口 & 人口\% & 玨事佱会加 & $\begin{array}{l}\text { 加重票数地场 } \\
\text { 加率 }\end{array}$ & 票数\% & 人口/票数 & \begin{tabular}{|l|} 
欧州議会諸席数 \\
\end{tabular} & \begin{tabular}{|l|} 
議席の \\
縮小卒 \\
\end{tabular} & 議席\% & 人口/議席 & 欧州委員委数 \\
\hline ド イ ツ & 8,204 & 21.9 & 29 & 2.9 & 12.2 & 283 & 99 & 100.00 & 23 & 829 & 1 \\
\hline イタリ ア ア & 5,761 & 15.3 & 29 & 2.9 & 12.2 & 199 & 72 & 82.76 & 17 & 800 & 1 \\
\hline イギリス & 5,925 & 15.8 & 29 & 2.9 & 12.2 & 204 & 72 & 82.76 & 17 & 823 & 1 \\
\hline フランス & 5,897 & 15.7 & 29 & 2.9 & 12.2 & 203 & 72 & 82.76 & 17 & 819 & 4 \\
\hline スペイン & 3,939 & 10.5 & 27 & 3.375 & 11.4 & 146 & 50 & 78.13 & 12 & 788 & 1 \\
\hline オランダ & 1,576 & 4.2 & 13 & 2.6 & 5.5 & 121 & 25 & 80.65 & 6 & 630 & 1 \\
\hline ポルトガル & 998 & 2.7 & 12 & 2.4 & 5.1 & 83 & 22 & 88.00 & 5 & 454 & 1 \\
\hline ギリシャ & 1,053 & 2.8 & 12 & 2.4 & 5.1 & 3.00 & 22 & 88.00 & 5 & 479 & 1 \\
\hline ベル ギー & 1,021 & 2.7 & 12 & 2.4 & 5.1 & 85 & 22 & 88.00 & 5 & 464 & 1 \\
\hline スウェーデン & 885 & 2.4 & 10 & 2.5 & 4.2 & 89 & 18 & 81.82 & 4 & 492 & 1 \\
\hline オーストリア & 808 & 2.2 & 10 & 2.5 & 4.2 & 81 & 17 & 80.95 & $I$ & 475 & 1 \\
\hline デンマーク & 531 & 1.4 & 7 & 2.333 & 3.0 & 76 & 13 & 81.25 & 3 & 408 & 1 \\
\hline フィンランド & 516 & 1.4 & 7 & 2.333 & 3.0 & 74 & 13 & 81.25 & 3 & 397 & 1 \\
\hline アイルランド & 374 & 1.0 & 7 & 2.333 & 3.0 & 53 & 12 & 80.00 & 3 & 312 & 1 \\
\hline ルクセンブルグ & 43 & 0.1 & 4 & 2.0 & 1.7 & 11 & 6 & 100.00 & 1 & 72 & 1 \\
\hline 計 & 37,531 & 100 & 237 & 2.724 & 100 & 158 & 430 & 68.69 & 100 & 873 & 15 \\
\hline 可 決多数 & & & 169 & & 71.3 & & & & & & \\
\hline 否 決多 数 & & & 69 & & 29.1 & & & & & & \\
\hline
\end{tabular}


ニース条約による $\mathrm{EU}$ 主要機関及び政策決定の改革（鷲江）

27カ国

\begin{tabular}{|c|c|c|c|c|c|c|c|c|c|}
\hline 国 & 人口 & 人口\% & $\begin{array}{l}\text { 理事会加 } \\
\text { 票数 }\end{array}$ & 票数\% & 人口/票数 & 欧詶議会 & 議席\% & 人口/議席 & 欧州委員会数 \\
\hline " & 8,204 & 17.1 & 29 & 8.4 & 283 & 99 & 13.5 & 829 & 1 \\
\hline $\begin{array}{llll}\text { イ } & \text { 夕 } & リ & ア \\
\end{array}$ & 5,761 & 12.0 & 29 & 8.4 & 199 & 72 & 9.8 & 800 & 1 \\
\hline イ ギ リ ス & 5,925 & 12.3 & 29 & 8.4 & 204 & 72 & 9.8 & 823 & 1 \\
\hline フ ラ ン ス & 5,897 & 12.3 & 29 & 8.4 & 203 & 72 & 9.8 & 819 & 1 \\
\hline ス ペ イ ン & 3,939 & 8.2 & 27 & 7.8 & 146 & 50 & 6.8 & 788 & 1 \\
\hline ポーランド & 3,867 & 8.0 & 27 & 7.8 & 143 & 50 & 6.8 & 773 & 1 \\
\hline ル $-\nabla=P$ & 2,249 & 4.7 & 14 & 4.1 & 161 & 33 & 4.5 & 682 & 1 \\
\hline オ ラ ン ダ & 1,576 & 3.3 & 13 & 3.8 & 121 & 25 & 3.4 & 630 & 1 \\
\hline ポル ト ガル & 998 & 2.1 & 12 & 3.5 & 83 & 22 & 3.0 & 454 & 1 \\
\hline ギリ リ シ & 1,053 & 2.2 & 12 & 3.5 & 88 & 22 & 3.0 & 479 & 1 \\
\hline$\exists$ & 1,029 & 2.1 & 12 & 3.5 & 86 & 20 & 2.7 & 515 & 1 \\
\hline ベ ル ギ & 1,021 & 2.1 & 12 & 3.5 & 85 & 22 & 3.0 & 464 & 1 \\
\hline ハン ガ リ - & 1,009 & 2.1 & 12 & 3.5 & 84 & 20 & 2.7 & 505 & 1 \\
\hline スウェーデン & 885 & 1.8 & 10 & 2.9 & 89 & 18 & 2.5 & 492 & 1 \\
\hline ブ ル ガ リ & 823 & 1.7 & 10 & 2.9 & 82 & 17 & 2.3 & 484 & 1 \\
\hline オーストリア & 808 & 1.7 & 10 & 2.9 & 81 & 17 & 2.3 & 475 & 1 \\
\hline スロバキア & 539 & 1.1 & 7 & 2.0 & 77 & 13 & 1.8 & 415 & 1 \\
\hline デンマーク & 531 & 1.1 & 7 & 2.0 & 76 & 13 & 1.8 & 408 & 1 \\
\hline フィンランド & 516 & 1.1 & 7 & 2.0 & 74 & 13 & 1.8 & 397 & 1 \\
\hline アイルランド & 374 & 0.8 & 7 & 2.0 & 53 & 12 & 1.6 & 312 & 1 \\
\hline リトア & 370 & 0.8 & 7 & 2.0 & 53 & 12 & 1.6 & 308 & 1 \\
\hline ラ $ト \begin{array}{lll} & \vdash & \text { ア }\end{array}$ & 244 & 0.5 & 4 & 1.2 & 61 & 8 & 1.1 & 305 & 1 \\
\hline スロベニア & 198 & 0.4 & 4 & 1.2 & 50 & 7 & 1.0 & 283 & 1 \\
\hline$I \pi 卜=ア$ & 145 & 0.3 & 4 & 1.2 & 36 & 6 & 0.8 & 242 & 1 \\
\hline キ プ ロ ス & 75 & 0.2 & 4 & 1.2 & 19 & 6 & 0.8 & 125 & 1 \\
\hline ルクセンブルグ & 43 & 0.1 & 4 & 1.2 & 11 & 6 & 0.8 & 72 & 1 \\
\hline 夕 & 38 & 0.1 & 3 & 0.9 & 13 & 5 & 0.7 & 76 & 1 \\
\hline 計 & 48,117 & 100 & 345 & 100 & 139 & 732 & 100 & 657 & 27 \\
\hline 可 決 多 数 & & & 255 & 73.9 & & & & & \\
\hline 否 決 多 数 & & & 91 & 26.4 & & & & & \\
\hline
\end{tabular}

・人口は特に記さない場合には，全て 1 万人単位で表示。

・1995年の人口は，世界国勢図会 CD-ROM '98/99より作成。

-2005年 1 月 1 日以降の人口は, COM（2000）34, 26 January 2000より作成。

・政府間会議が採択した最終規定に付属する以下の宣言より作成。

20. 欧州同盟の拡大に関する宣言

21. 拡大した同盟における特定多数決の閾値及び阻止少数のための票数に関する宣言 
『日本 $\mathrm{EU}$ 学会年報』第 22 号, 平成14年 9 月

全体的な傾向としては，新規加盟国に対する議席配分は，新規加盟国間の扱い の違いというよりも，既存の加盟国と新規加盟国との間の差別化の結果として， 一部の新規加盟国の議席数が相対的に少なく配分されているのである。

（3）16力国一26力国体制の場合

欧州議会の議席の新たな加盟国別配分は，欧州議会の議員の改選に合わせて 行われる予定であり，2005年からの新規定の適用を予定する理事会や欧州委員 会とは異なり，2004年 6 月の次回の欧州議会選挙の際に適用される予定である。 他の機関に比べて新規定の実施時期が早いため，欧州議会に関しては，他の機 関に関するものよりも柔軟な規定が用意されている。

欧州議会の議席の加盟国への配分は，原則的には，2004年 1 月 1 日の加盟国 に対して成される。しかし，この時点での加盟国が27カ国未満の場合には，以 下の 3 つの原則が適用される。1）欧州議会の総議員数は732議席にできるた け近い数を確保すること。2）732議席の上限を超えない範囲内で，加盟国の 新しい議席の配分比率に応じた追加議席を配分することが可能なこと。3）た だし，この再配分は現在の1999年ー2004年任期の欧州議会の議席配分数を超え ない範囲で行われることである。そのため, ドイツとルクセンブルグに関して は，いかなる場合でも欧州議会の議席数は現行のままである。他の加盟国につ いては，新規加盟国も含めて，2004年 1 月 1 日時点での加盟国によって，次回 の欧州議会議員選挙の際に加盟国に配分される議席数は，変動する可能性が残 されている。もっとも，2004年 1 月 1 日時点で, 未加盟国への配分予定議席を 既存の加盟国に再配分するのか否か，再配分する場合の議席を何議席にするの か, あるいは2004年以降の新規加盟国への議席配分をも考慮に入れて議席を留 保するのかなど，2004年以降の次期の欧州議会の議席数を実際にどのように設 定するかは，今後の加盟交渉の進展状況によって大きく左右される可能性を持 っている。そのため, これらの議席に関する最終的な調整は, 今後の理事会で 具体的に決定される予定である。また，2004年にその時点での加盟国間での議 席の追加配分を理事会が決定した後に，新規加盟国が加盟する場合に備えて， 
新規加盟国への議席配分による欧州議会の総議席の一時的超過についても許容 している。このため次期の欧州議会では総議員数が732議席を越える可能性も 残されているのである（欧州同盟の拡大に関する議定書 2 条 4 項)。

以上のような欧州議会議席の再配分によって，各加盟国の議席は加盟国の人 口比をより反映するものとなっている。しかし，ドイッとルクセンブルグだけ が議席数の変更を行わなかった結果，1議席に代表される人口の格差（1票の格 差）は，ドイッとルクセンブルグの間で，依然として12倍も存在している。し かも，ルクセンブルグとマルタの間に 1 議席の差を設けたために，1票の格差 の問題が人口が最大のドイツと最小のマルタの間ではなく, ドイッとルクセン ブルグの間に存在する結果となっている。また，既存の加盟国間あるいは，新 規加盟国の間でも議席数の配分に格差が見られるが，理事会の加重票数の再配 分及び欧州委員会の委員数の変更との間のバランスを考慮に入れた加盟国間の 取引が行われており，欧州議会の議席の多寡だけを論じるのではなく，全体的 な視点から分析が必要である。とはいえ，欧州議会の機関としての特性を考え た場合，加盟国の人口比を最も反映するべき欧州議会の議席数の配分が，他の 機関における加盟国の影響力の減少あるいは増大を補填する材料となっており， 今回の改定でも加盟国の議席が人口比たけを反映するものとはなっていないこ とは，今後の欧州議会の大きな課題となるであろゔ。

\section{2 理 事 会}

\section{1 理事会の加重票数と特定多数決}

現在の理事会の特定多数決方式は, 各加盟国に一定の票数を加重配分し，そ の総加重配分票数の内の一定数の賛成票が得られた場合に可決される決定方式 である。ただし，現行条約では，対象となる案件が欧州委員会提案に基づかな い場合にのみ $2 / 3 の$ 加盟国の賛成が可決のための要件として追加される。各加 盟国の加重票数については，1973年の第 1 次拡大の際に全面的に改定されたの 
『日本 $\mathrm{EU}$ 学会年報』第 22 号, 平成14年 9 月

みで，今日まで根本的な票の再配分は行われてこなかった。理事会の加重票数 の主な特徵は，各加盟国の人口をある程度考慮しつつも(人口比例)，4大国 (独，英，仏及び伊）間の票数の平等を保ち（大国の平等），中小の加盟国には人 口比より多くの票を配分し（小国の主権の擁護），さらに新規加盟国には，類推 的に（主に人口規模に応じて）票数を配分するというものであった。しかし，中 小国の増加やドイツ統一による既存の加盟国間での加重票数配分の不平等感の 増大，さらには27カ国への大幅な拡大を目前にして，理事会の加重票数配分及 び特定多数決制は根本的な見直しを迫られたのである。

今回検討された課題は，1）可決のための要件に加盟国の過半数以上という 要件を条約に明記するかどうか。2）可決に必要な賛成票を全体の何\%にする か。3）加重票数を再配分する場合に，既存の加盟国の配分バランスを維持す るかどうか。4）どのような形式及び数字が決定の基盤となるべきかなどであ つた。

最終的には，EUの拡大に伴う理事会の加重票数及び特定多数決の方式に関 する変更は，欧州議会と同じく「欧州同盟の拡大に関する議定書」 3 条におい て規定されている。以下では, ニース条約の規定に従って, 理事会の加重票数 の再配分と特定多数決の方式を15力国，27力国，16-26力国の場合に分けて検 討していくことにしたい（以下表 1 を参照されたい)。

\section{215 力国体制の場合}

(1) 加重票数の再配分

今回改定された既存の15の加盟国の理事会における新たな加重票数は，2005 年 1 月 1 日から適用される。この改定により, 各加盟国の加重票数は, 欧州議 会における議席配分とは対照的に，大幅に拡大再配分されることになった。た だし，ここでも加盟国によってその増加率はかなり異なっている。いくつか特 徵を列挙すれば，1）スペインを筆頭にいわゆる大国の増加率が大きいのに対 して，オランダ以下の中小国の増加率は，相対的に少ないものとなっている。 
ニース条約による $\mathrm{EU}$ 主要機関及び政策決定の改革（鶉江）

そのため，各加盟国の加重票数は，従来よりも加盟国の人口比に近いものとな

り，理事会における大国の影響力が増大する結果となっている。2）ただし， 4 大国間の平等な票数配分は，今回の改定でも依然として維持されたため，人 口面では2500万人程度の格差のあるドイツと他の大国間の不平等感は依然とし て顕著なままである。3）中小国の中では，EEC 設立以来常に同票国であっ たオランダとベルギーの間に今回初めて 1 票の格差が付けられているのが注目 される。4）全体の加重票数が87票から237票に大幅に増大した結果，可決に 必要な賛成票も62票から169票に大幅に増加しているが，全体の加重投票数に 占める賛成必要票の割合は，ほとんど同じである（現在の71.26\%から71.31\%に 微増)。

（2）新しい可決要件の導入

表 2

\begin{tabular}{|c|c|c|}
\hline & 欧州委員会の提案に基づく場合 & 欧州委員会の提案に基づかない場合 \\
\hline 従 来 の要 件 & 可決に必要な賛成票数（71\%前後） & $\begin{array}{l}\text { 可決に必要な賛成票数（71\%前後） } \\
\text { 加盟国の } 2 / 3 \text { 以上 }\end{array}$ \\
\hline $\begin{array}{l}\text { ニース条約発効以 } \\
\text { 降の要件 } \\
\text { (15力国) }\end{array}$ & $\begin{array}{l}\text { 可決に必要な賛成票数（71\%前後） } \\
\text { 加盟国の過半数以上 } \\
\text { 全人口の } 62 \% \text { 以上 }\end{array}$ & $\begin{array}{l}\text { 可決に必要な賛成票数（71\%前後） } \\
\text { 加盟国の } 2 / 3 \text { 以上 } \\
\text { 全人口の } 62 \% \text { 以上 }\end{array}$ \\
\hline $\begin{array}{l}\text { ニース条約発効以 } \\
\text { 降の要件 } \\
\text { (27力国) }\end{array}$ & $\begin{array}{l}\text { 可決に必要な賛成票数 }(74 \%) \\
\text { 加盟国の過半数以上 } \\
\text { 全人口の } 62 \% \text { 以上 }\end{array}$ & $\begin{array}{l}\text { 可決に必要な賛成票数 }(74 \%) \\
\text { 加盟国の } 2 / 3 \text { 以上 } \\
\text { 全人口の } 62 \% \text { 以上 }\end{array}$ \\
\hline
\end{tabular}

今回の特定多数決方式の改定の中で最も注目されるのは，欧州委員会の提案 に基づいて理事会が決定する場合に，従来から必要とされていた一定の賛成票 数要件に加えて 2 つの要件が追加されたことである（以下表 2 を参照されたい)。 第 1 は, 加盟国の過半数の賛成を必要とするという必要最低加盟国数の要件で ある。現在の15力国体制の EUにおいては，可決に必要な票数を満たす最少 の加盟国の連合の場合でも加盟国数は 8 力国であり，過半数の加盟国の賛成と いう要件は票数要件を満たす連合においては常に充足される。しかし今回の加 重票数の改定と将来の拡大によって，2つの要件が常に同時に満たされるとは 
『日本 $\mathrm{EU}$ 学会年報』第 22 号, 平成 14 年 9 月

限らないため，中小国に配慮する形で，今回新たに導入された要件である。

もう 1 つの要件は人口要件である。これは, 賛成票を投じた加盟国の人口の 総和が，EUの全人口の $62 \%$ 以上占める必要があるとする要件である。この 人口要件は加盟国数要件とは逆に，人口面で優位な大国の影響力を増大させる ものであると同時に，ドイツと他の 3 大国間の影響力の明確な差別化をもたら すものとなっている。加重票数の配分においては，4大国とも29票が配分され ることによって，見かけ上は，従来通りの大国間の平等が貫かれてはいるもの の，加盟国の人口という新たな要因を可決要件に導入したことによって，実際 には，ドイツと他の 3 大国の間に実質的な格差を設けたのである。

\section{327 力国体制の場合}

新規加盟予定国への加重票数の配分は, 欧州議会の議席配分と同様に加盟国 によって若干の格差が存在している。特に加盟国の人口と加重票数の比率から 見るとルーマニア, ラトビア, マルタの 3 力国は, 他の 9 力国に比べて相対的 に少ない配分となっている。その中でも，人口で 5 万人の差しかないルクセン ブルグとマルタの間に 1 票の格差を付けたことは，議長国フランスのシラク大 統領もニース欧州理事会後の記者会見で認めているように，原加盟国への政治 的配慮による票数配分である。

この27カ国に配分された加重票数によって, 理事会が欧州委員会の提案に基 づいて採択する場合には，人口要件（EUの全人口の $62 \%$ 上）及び必要加盟国 数要件 (過半数以上) の 2 つの要件は，15力国体制の場合と同様である。しか しながら，可決に必要な賛成票数に関しては，従来の71\%前後から $73.9 \%$ (345票中の 255 票) 以上へとかなり引き上げられている。このため，新たに導入 される 2 つの要件に加えて，従来からの可決に必要な票数要件に関しても，以 前よりもかなり高い設定がなされているのである。 


\subsection{6力国一 26 力国体制の場合}

2005年 1 月 1 日の時点で，新規加盟を予定している加盟国の中で依然として 未加盟の国がある場合は，加盟が完了した加盟国のみに加重票数配分が行われ る。この場合，特定多数決によって可決するための 3 つの要件のうち加盟国数 要件及び人口要件は，機械的に計算が可能であるが，可決に必要な票数の設定 はその時点での加盟国に関して，さらには新たな拡大の度に設定される必要が ある。そのため，ニース条約に付属する「拡大した同盟における特定多数決の 閾値及び阻止少数のための票数に関する宣言」によって，その具体的票数は, その時点での加盟国の全加重票数の $71.26 \%$ から最大 $73.4 \%$ ま゙の間の整数值 を適用されることになっている。

\section{5 新しい要件の意味}

27 国の EU 体制においては，欧州委員会の提案に基づいて理事会が特定 多数決で決定する場合には，人口要件及び加盟国数要件の導入によって以下の ケースが起こりうる（以下表 3 を参照されたい）。

表 3

人口条項の効果（27力国体制）

\begin{tabular}{|c|c|c|c|c|c|}
\hline & 賛成する加盟国 & 加盟国数 (14) & 加重票数 (255) & 人口比率 $(62 \%)$ & 結果 \\
\hline ケース I & 独, 英, 仏, マルタを除く23カ国 & $23 \bigcirc$ & 2550 & $58 \% \times$ & 否決 \\
\hline ケース 2 & 伊, 英, 仏, マル夕を除く23力国 & $23 \bigcirc$ & 2550 & $63 \% \bigcirc$ & 可決 \\
\hline
\end{tabular}

加盟国数要件の効果（27力国体制）

\begin{tabular}{|c|c|c|c|c|c|c|}
\hline & 反対する加盟国 & 加盟国数 (14) & 加重票数 (91) & 人口比率 & $(38 \%)$ & 結果 \\
\hline ケース 3 & スウェーデン以下の14カ国 & $14 \bigcirc$ & $88 \times$ & $12 \%$ & $x$ & 否決 \\
\hline ケース 4 & 独, 仏, 伊, マル夕 & $4 \times$ & $90 \times$ & $37 \%$ & $\times$ & 可決 \\
\hline
\end{tabular}

ケース 1 とケース 2 の相違は，反対票を投じる 4 カ国の連合にドイツが参加 するかあるいはそれに代わってイタリアが反対するかのみである。可決に必要 な加盟国数及び加重票数の要件に関しては，どちらの場合も充足しているが, 
『日本 $\mathrm{EU}$ 学会年報』第22号, 平成14年 9 月

賛成する加盟国の EU の全人口に占める人口比率が異なっているため，人口 要件だけによって, 可決か否決かの結果が分かれることになる。この人口要件 は，大国，特にドイツの影響力を増大させているといえよう。また，これまで は，賛成する加盟国の人口が $\mathrm{EU}$ 全体の $60 \%$ に満たない中小の加盟国の連合 の場合でも可決が可能であったが，人口要件の導入は，人口の少ない加盟国に 不利に㗢くため, 多数の中小加盟国の連合による可決を阻止する効果を持って いるのである。

他方, 加盟国数要件は, 今回の加重票数の再配分において相対的に不利な改 定をされ，国益の擁護が益々困難になった中小国の影響力の低下をある程度補 うものとなっている。この要件は，大国主導の政策決定になるのを防止するた めであり，相対的に人口の多い加盟国の少数の連合による可決を阻止する効果 を持つ。そのため, 多数の中小国が反対した場合, 賛成票数要件及び人口要件 のいずれも充足しないものの, 加盟国数要件のみによって否決することが可能

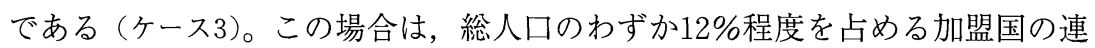
合でも否決することが可能となっているが，他方ではケース 4 のように大国中 心の連合の場合には，人口面では，前記の連合の 3 倍以上を構成する加盟国に よる連合にも関わらず，いずれの要件も充足しないため，否決することができ ないのである。

以上のように, これら 2 つ要件は，全く逆の効果をもたらすものの，それ ぞれ従来は可能であった可決のための加盟国の連合を排除する結果となり，可 決に必要な敷居を従来より高めることになっている。また，これらの要件に加 えて，可決に必要な票数要件も $73.9 \%$ れまま゙以上に多くの票数が必要とさ れる厳しい要件となっている。そのため，加盟国数の増大による加盟国間の利 害のさらなる多様化をも考えれば，理事会における特定多数決の適用範囲を拡 大したとしても，特定多数決による可決自体が困難になる可能性が大きくなり つつあるともいえよゔ。 


\section{3 欧州委員会}

\section{1 欧州委員会の任命手続き}

これまでの条約改定（マーストリヒト条約及びアムステルダム条約）によって， 欧州委員会の任命に関しては，欧州議会の参画による欧州委員会の民主的正当 性の向上が図られるとともに，委員長と他の委員の任命過程の差別化による委 員長の政治的権威付けが計られてきた（以下図１を参照されたい)。今回のニー ス条約ではさらに以下の改革が行われている。

ニース条約では，欧州委員会委員長の任命主体が，加盟国政府から EU の 正式な機関である首脳理事会に変更されたことのみならず，決定方式がコンセ ンサス方式から特定多数決に変更された。従来は, 全ての加盟国の合意が前提 条件であり, そのため, 1 カ国でも反対する場合は, 委員長候補の指名は不可 能であった。EUの27カ国への拡大は, 現在よりもさらに全会一致での決定が 困難になることを意味しており，特定多数決の導入は，委員長を任命できない という異常事態を回避するための制度的な対応である。しかし, 委員長の指名 という重要な案件に関する加盟国の主権の制限を意味するこの改革は，今後の 委員長と加盟国の関係のみならず，EUと加盟国の関係にも大きな変化をもた らす可能性を持つかなり大胆な改革である。

さらに，他の委員の指名に関しても委員長候補と合意形成を行うのは加盟国 ではなく理事会となり, さらに理事会の同意も特定多数決によって行われるよ うに改定されている。委員長の指名とその他の委員の指名の主体は, 従来は同 じく加盟国であったが，今回の改定によって, 委員長は首脳理事会, 他の委員 は理事会と明確な区別が付けられており，委員長の政治的権威の一層の向上が 図られるものとなっている。また, 最終的に欧州委員会を任命する主体も加盟 国政府から理事会に変更され，任命手続き方式も加盟国の合意から特定多数決 に変更されたのである。 
『日本 $\mathrm{EU}$ 学会年報』第 22 号, 平成 14 年 9 月

図 1 欧州委員会の任命手続き

A．マーストリヒト条約以前（旧158条）

加盟国政府の合意

$\downarrow$ 任命（任期4年）

欧州委員会全委員

B．マーストリヒト条約以降（旧158条）

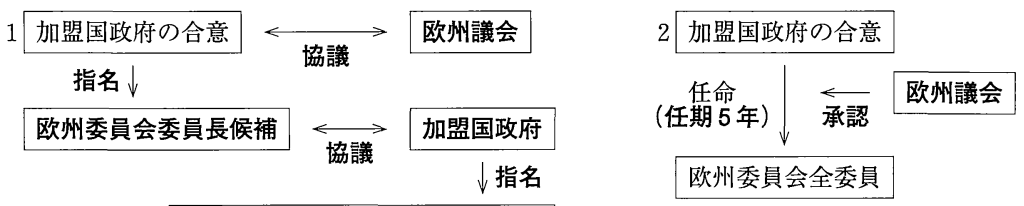

委員長以外の欧州委員会委員候補

C．アムステルダム条約以降（214条）
1 加盟国政府の合意
2 加盟国政府の合意
指名 承認 欧州議会

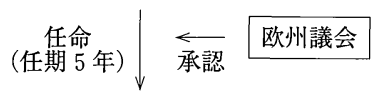
欧州委員会委員長候補
$\underset{\text { 合意 }}{\longrightarrow} \frac{\text { 加盟国政府 }}{\downarrow \text { 指名 }}$
欧州委員会全委員
委員長以外の欧州委員会委員候補

D. ニース条約発効以降 (214条)

1 首脳理事会の特定多数決

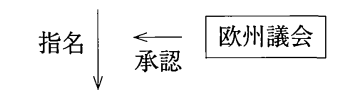

欧州委員会委員長候補
理事会の

特定多数決

$\downarrow$ 指名
2 理事会の特定多数決

(任期 5 年) $\downarrow$ 承認 欧州議会

欧州委員会全委員

\section{委員長以外の欧州委員会委員候補名簿 (加盟国政府の提案に基ついて作成)}

（注）太ゴチックが変更点 
なお，欧州委員会の任命手続きの変更に関連し，欧州委員会委員の辞任，罷 免，もしくは死亡の場合に生じる空席の補充に関する手続きも変更されている (EC 条約215条)。その結果，空席が生じた場合の欠員補充も新規の任命の場合 と同じく, 理事会の特定多数決で行われる。しかし，この規定によれば，新し い欧州委員会委員の任命に関しては，欧州議会による承認及び欧州委員会委員 長の合意も不要である。そのため, 補充された委員に対する民主的正当性の付 与と委員長の関与がどこまで認められるのかという問題が依然として残された ままである。

\section{2 欧州委員会委員長の政治的指導力}

欧州委員会委員長の政治的指導力に関しては，アムステルダム条約において すでに明記されていたが，ニース条約によってより具体的な権限が条約に列挙 されることになった（EC 条約217条）。すなわち，欧州委員会は，委員長の政治 的指針の下で活動し，委員長自身が政治的責任を持って，

・欧州委員会の内部組織を決定する (1項)。

・委員長は，欧州委員会の職務を体系化し，それを各委員に配分する ( 2 項)。 ・一旦配分した職務でも, 欧州委員会の任期中に各委員に職務を再配分できる ( 2 項)。

・副委員長を任命する（全委員の承認が必要）( 3 項)。

・委員長が要請した場合には, 各委員は個別に辞任させられる（全委員の承認 が必要) ( 4 項)。

この改定によって, 欧州委員会の委員長の権限は, かなり広範かつ強力なも のとなっており，委員長の政治的権威が増大していることが見て取れる。しか し, 副委員長の任命と個別の委員の辞職に関しては, 欧州委員会の全委員の承 認を必要とするため, 実際に委員長の政治的判断が優先されるかどうは依然と して不明確である。また，すでに述べたように，委員の辞任による新委員の任 命に関しては，委員長の役割についての言及がなく，委員の罷免と任命に関す 
『日本 $\mathrm{EU}$ 学会年報』第 22 号, 平成14年 9 月

る委員長の指導力がどこまで発揮できるかも今後の課題であろう。

\section{3 欧州委員会の委員数の変更}

(1) 欧州委員会の肥大化

現在の欧州委員会の委員は，各加盟国からの 2 名以内の委員で構成される。 条約上は，どの加盟国も2 名の委員を出す権利を有しているものの現在は，一 種の慣行として大国から 2 名，その他の中小の加盟国から 1 名づつの委員で構 成されている。その結果，委員数は，欧州議会の場合と同じく加盟国が増大す るにしたがって，ほぼ自動的に増加してきた。現在の制度をそのまま維持すれ ば，現在20名の欧州委員会は，今後の拡大によって増大し続け，加盟予定の12 カ国全てが加盟すれば，33名の規模となる。欧州委員会の無制限の肥大化に対 しては, 委員長の指導力の強化による効率性の維持が図られる一方で, 委員の 数の抑制が課題として挙げられてきた。アムステルダム条約に付属する「欧州 同盟の拡大を想定した機関に関する議定書」においても，一定の条件の下で，

委員を各加盟国からの1名づつの国民によって構成するよう求めている。その ため，今回の改定では，加盟国数が 26 力国以下の場合と 27 力国以上の場合の 2 段階に分けた欧州委員会の委員数の削減を規定している(「欧州同盟の拡大に関 する議定書」4条)。

(2) 26力国以内の場合

現在のプロディー欧州委員会の任期が終了する2005年 1 月の時点で, 加盟国 の総数が 26 国以下の場合, 次期の欧州委員会は, 各加盟国から各 1 名の委員 によって構成される。また，2005年以降の新規加盟国に対しても，加盟に伴っ て1名の委員を出す権利が与えられており，2005年 1 月以降に任命される欧州 委員会の委員数は加盟国と同数になる予定である。

（3） 27 力国以上の場合

EUが27カ国以上になった場合には，27番目の加盟国が加盟した日以降に任 命される最初の欧州委員会から，輪番制が導入され，委員数のさらなる削減が 
行われる予定である。委員数についての原則は a ) 委員の総数は, 加盟国数未 満とすること。 b ) 加盟国間の平等の原則を基礎とし， 2 期連続して委員を出 せない加盟国がないようすること。c）欧州委員会の構成は，加盟国の人口分 布及び地理的な広がりを十分に反映するように考慮されるものとすることの 3 点である。

したがって，27カ国体制の場合，EUにおける委員数は，a）及びb）の原 則からすれば，14名から 26 名の間で設定されることになるが，具体的な人数に ついては，今後の理事会による全会一致の決定にゆだねられており依然として 未確定である。また，この輪番制の具体的な実施内容に関しても原則のみが示 されただけであり，いかなる方式によって加盟国の人口分布と地理的な広がり を反映するのかも今後の理事会の決定事項とされている。

ニース条約による欧州委員会の定数削減は，大国からの委員を 1 名削減する という点でかなり画期的なものである。もっとも, 大国の影響力の低下の補償 として, 欧州議会の議席の再配分や理事会での加重投票数の再配分では，大国 が優遇されるなど，欧州委員会の定員削減も主要機関の構成員の加盟国別配分 の全体的バランスに配慮した結果であった。しかし，次の段階の輪番制が導入 されれば，EUの主要機関に代表を送れない加盟国が存在することになり，も し実現すれば，欧州委員会の任命過程における特定多数決制の導入と同じく， 加盟国と EUの関係を根本的に見直す可能性を持つものであるといえよう。

\section{4 政策決定に関する改定}

政策決定手続きに関する主要な改定は，理事会における決定の一部を全会一 致方式から特定多数決方式に移行すること及び欧州議会の権限拡大を意味する 同意手続や共同決定手続きなどの適用範囲を拡大したことである。共同決定手 続きに関しては，アムステルダム条約によって手続き過程が簡素化されたが， 今回の改定では，新たな政策決定方式の導入や共同決定手続きの手続きに関す 
『日本 $\mathrm{EU}$ 学会年報』第22号，平成14年 9 月

る変更はなく，共同決定手続きの適用範囲を広げることのみにとどまっている。 ニース条約によって改定された EU 条約及び EC 条約に関しては34項目で ニース条約の発効以降直ちに，10項目については一定の条件の下で政策決定方 式の変更が行われている。政策決定に関する改定に関しては，詳細は以下の表 4 の通りであるが，ここではいくつかの特徴を列挙することにしたい。

表 4 ニース条約による EU の政策決定手続きの変更

1. ニース条約の発効によって新しい手続きが導入される条項

1) $\mathrm{EU}$ 条約に関する変更

\begin{tabular}{|c|c|c|c|}
\hline 条 & 内 & 新手続き形式 & 現行手続き形式 \\
\hline 7 条 1 項 & $\begin{array}{l}\mathrm{EU} \text { の諸原則に対する加盟国による重 } \\
\text { 大な違反が生じる明確な危険の確認と } \\
\text { 当該国への適切な勧告の提出 }\end{array}$ & $4 / 5$ 多数決*1 & 新規規定 \\
\hline 23 条 2 項 1 段 & $\begin{array}{l}\text { 特定の任務を与えられる特別代表の任 } \\
\text { 命 }\end{array}$ & 理事会特定多数決*2 & 詳細なし \\
\hline 24 条 3 項 & $\begin{array}{l}\text { 統一行動または共通の立場の採択を必 } \\
\text { 要とする協定*3 }\end{array}$ & 理事会特定多数決*4 & 理事会全会一致 \\
\hline 24 条 4 項 & $\begin{array}{l}\text { VI 編に属し, 域内の決定あるいは措 } \\
\text { 置を採択するために理事会での特定多 } \\
\text { 数決が必要とされる事項を含む協定 }\end{array}$ & 理事会特定多数決 & 理事会全会一致 \\
\hline $27 \mathrm{c}$ 条 & $\begin{array}{l}\text { 共通外交・安全保障政策におけるより } \\
\text { 緊密な協力 }\end{array}$ & 理事会特定多数決 & 新規規定 \\
\hline $27 \mathrm{e}$ 条 & $\begin{array}{l}\text { より緊密な協力への参加を望む加盟国 } \\
\text { への対応 }\end{array}$ & 理事会特定多数決 & 新規規定 \\
\hline
\end{tabular}

* 1 加盟国の 3 分の 1 , 欧州議会あるいは委員会による正当な提案に基づき, 欧州議会の同意を得 た後，理事会は行為する。

*2 ただし，EU 条約 23 条 2 項により，理事会の構成員が，国家政策の重要かつ公表された理由に より，特定多数決によって決定の採択が行われることに反対する意思のある場合，投票は行われ ない。理事会は, 全会一致で決定を行う欧州理事会にその事項が付託されることを, 特定多数決 の議決により要求することができる。

*3 域内の決定を採択するために全会一致が必要とされる問題をその協定が包含する場合，理事会 は全会一致で行為する。

*4 ただし, EU 条約 23 条 2 項により, 理事会の構成員が, 国家政策の重要かつ公表された理由に より，特定多数決によって決定の採択が行われることに反対する意思のある場合，投票は行われ ない。理事会は, 全会一致で決定を行う欧州理事会にその事項が付託されることを, 特定多数決 の議決により要求することができる。 
2) EC 条約

共同体の政策に関する変更

\begin{tabular}{|c|c|c|c|}
\hline 条 & 容 & 新手続き形式 & 現行手続き形式 \\
\hline 11条 & $\begin{array}{l}\text { より緊密な協力が共同決定手続きを利 } \\
\text { 用す分野に関係する場合*1 }\end{array}$ & $\begin{array}{l}\text { 同意手続き（特定多数 } \\
\text { 決） }\end{array}$ & $\begin{array}{l}\text { 諮問手続き（特 } \\
\text { 多数決） }\end{array}$ \\
\hline 13 条 2 項 & 反差別促進措置 & 共同決定手続き & 新規規定 \\
\hline 18条 2 項 & $\begin{array}{l}\text { EU 市民の移動及び居住の自由の促進 } \\
\text { 措 }\end{array}$ & 共同決定手続き & $\begin{array}{l}\text { 共同決定手続 } \\
\text { き }\end{array}$ \\
\hline 65 条*3 & 家族法を除く民事司法協力 & 共同決定手続き & $\begin{array}{l}\text { 諮問手続き（全 } \\
\text { 会一致）*4 }\end{array}$ \\
\hline 100 条 1 項 & 困難な経済情勢に関する措置 & $\begin{array}{l}\text { 非諮問手続き（特定多 } \\
\text { 数決） }\end{array}$ & $\begin{array}{l}\text { 非諮問手続き } \\
\text { (全会一致) }\end{array}$ \\
\hline 100 条 2 項 & 加盟国への金融支援 & $\begin{array}{l}\text { 非諮問手続き（特定多 } \\
\text { 数決） }\end{array}$ & $\begin{array}{l}\text { 非諮問手続き } \\
\text { (全会一致)*5 }\end{array}$ \\
\hline 111 条 4 項 & $\begin{array}{l}\text { EMUに関する国際レベルでの共同体 } \\
\text { の代表の決定 }\end{array}$ & $\begin{array}{l}\text { 非諮問手続き（特定多 } \\
\text { 数決）*6 }\end{array}$ & $\begin{array}{l}\text { 非諮問 手続き } \\
\text { (全会一致)*7 }\end{array}$ \\
\hline 123 条 4 項 & ユーロ導入促進措置 & $\begin{array}{l}\text { 非諮問手続き（特定多 } \\
\text { 数決 } * 88 * 9\end{array}$ & $\begin{array}{l}\text { 非諮問手続き } \\
\text { (全会一致)*10 }\end{array}$ \\
\hline 133条 5 項 & $\begin{array}{l}\text { サービスに関する貿易の分野及び知的 } \\
\text { 所有権の商業的側面に関する協定の交 } \\
\text { 渉と締結 }\end{array}$ & 理事会特定多数決 & 新規規定 \\
\hline 137条 1 項*11 & $\begin{array}{l}\text { 社会的排除の撲滅及び社会的保護体制 } \\
\text { の近代化 }\end{array}$ & 共同決定手続き & 新規規定 \\
\hline 157 条 3 項 & 産業の競争力のための条件整備 & 共同決定手続き*12 & $\begin{array}{l}\text { 諮問手続き（全 } \\
\text { 会一致）*13 }\end{array}$ \\
\hline 159条 & $\begin{array}{l}\text { 構造基金以外の経済的及び社会的結束 } \\
\text { のため行動 }\end{array}$ & 共同決定手続き*14 & $\begin{array}{l}\text { 諮問手続き（全 } \\
\text { 会一致）*15 }\end{array}$ \\
\hline $181 \mathrm{a}$ 条 1 項*16 & $\begin{array}{l}\text { 第三国との経済的，財政的及び技術的 } \\
\text { 措置 }\end{array}$ & $\begin{array}{l}\text { 諮問手続き（特定多数 } \\
\text { 決) }\end{array}$ & 新規規定 \\
\hline
\end{tabular}

*1 それ以外の分野では, 諮問手続きが継続される。

*2 マーストリヒト条約によって新規に規定された現行の18条（旧 8 a 条）は, 共同決定手続きを 規定してはいるものの, 共同決定手続きの間の理事会の決定に対しては常に全会一致を求めるも のである。

*3 手続き内容は, 67 条 5 項で規定

*4 加盟国による発議も可能

* 5 原則的に理事会は全会一致で行為し, 一部のみ特定多数決を適用する。

*6, 7, 8, 10 ECB に諮問を必要とする。

* 9122 条 5 項を適用。

*11 手続きは, 137 条 2 項 ( b ) で規定。

$* 12,13$ 経済社会員会への諮問を必要とする。

* 14, 15 経済社会員会及び地域委員会への諮問を必要とする。

*16 手続きは, $181 \mathrm{a}$ 条 2 項で規定。

*17 連合協定及び加盟候補国との協定は全会一致が必要とされる（181 a 条 2 項）。 
『日本 $\mathrm{EU}$ 学会年報』第 22 号, 平成 14 年 9 月

機関の構成員の任命及び手続き規則に関する変更

\begin{tabular}{|c|c|c|c|}
\hline 条 項 & 内 & 新手続き形式 & 現行手続き形式 \\
\hline 190 条 5 項 & $\begin{array}{l}\text { 欧州議会議員の職務の遂行に関する規 } \\
\text { 則及ひ般的条件の承認 }\end{array}$ & 理事会特定多数決*1*2 & 理事会全会一致 \\
\hline 191条 & 欧州レベルでの政党の規律の制定 & 共同決定手続き & 新規規定 \\
\hline 207条 & $\begin{array}{l}\text { 理事会の事務局長及び副事務局長の任 } \\
\text { 命 }\end{array}$ & 理事会特定多数決 & 理事会全会一致 \\
\hline \multirow{3}{*}{214 条 2 項 } & 欧州委員会委員長候補の指名 & 首脳理事会特定多数決*3 & $\begin{array}{l}\text { 加盟国政府の共 } \\
\text { 通の合意*4 }\end{array}$ \\
\hline & 欧州委員会委員候補者名簿の採択 & 理事会特定多数決*5 & $\begin{array}{l}\text { 加盟国政府の共 } \\
\text { 通の合意*6 }\end{array}$ \\
\hline & 欧州委員会の任命 & 理事会特定多数決*7 & $\begin{array}{l}\text { 加盟国政府の共 } \\
\text { 通意*8 }\end{array}$ \\
\hline \multirow{2}{*}{ 215条 } & 欧州委員会委員の欠員補充 & 理事会特定多数決 & $\begin{array}{l}\text { 加盟国政府の共 } \\
\text { 通の合意 }\end{array}$ \\
\hline & 欧州委員会委員長の補充 & 214 条 2 項の手続き & $\begin{array}{l}214 \text { 条 } 2 \text { 項の手 } \\
\text { 続き }\end{array}$ \\
\hline 223条 & 司法裁判所手続き規則の承認 & 理事会特定多数決 & $\begin{array}{l}\text { 理事会全会一 } \\
\text { 致*9 }\end{array}$ \\
\hline 224 条 & 第 1 審裁判所手続き規則の承認 & 理事会特定多数決*10 & $\begin{array}{l}\text { 理事会全会一 } \\
\text { 致*11 }\end{array}$ \\
\hline 225 a 条 & 司法パネルの手続き規則の承認 & 理事会特定多数決*12 & 新規規定 \\
\hline 247 条 3 項 & 会計検查院の構成員の任命 & 理事会特定多数決*13 & $\begin{array}{l}\text { 理事会全会一 } \\
\text { 致*14 }\end{array}$ \\
\hline 248条 4 項 & 会計検査院手続き規則の承認 & 理事会特定多数決 & 新規規定 \\
\hline 259条 1 項 & 経済社会委員会構成員名簿の採択 & 理事会特定多数決*15 & $\begin{array}{l}\text { 理事会全会一 } \\
\text { 致*16*17 }\end{array}$ \\
\hline 263条 & $\begin{array}{l}\text { 地域委員会構成員及び代替要員名簿の } \\
\text { 据 }\end{array}$ & 理事会特定多数決*18 & $\begin{array}{l}\text { 理事会全会一 } \\
\text { 致*19 }\end{array}$ \\
\hline
\end{tabular}

*1 欧州委員会の意見を得た後に理事会は行為する。

*2 現職もしくは，前職の議員の税に関係する全ての規律もしくは条件は全会一致が必要とされる。

* 3, 4 理事会での指名の後, 欧州議会による承認を必要とする。

* 5, 6 委員長候補との合意を必要とする。

* 7, 8 欧州議会による承認の後に理事会は行為する。

*9 現行の EC 設立条約では，245条に規定。

*10 第一審裁判所が司法裁判所との合意に基づき，手続き規則を制定した後，理事会は行為する。

*11 現行の EC 設立条約では, 225条 4 項に規定。

*12 司法パネルが司法裁判所との合意に基づき，手続き規則を制定した後，理事会は行為する。

* 13, 14 欧州議会への諮問の後，理事会は行為する。

*15，16，18，19 加盟国の提案に基づいて，理事会は行為する。

$* 17$ 現行の EC 設立条約では, 258条で規定 


\section{ニース条約による EU 主要機関及び政策決定の改革（鷕江）}

2.ニース条約発効後，適用期日及び条件付きで新しい手続きが導入される条項

\begin{tabular}{|c|c|c|c|c|}
\hline 項 & 内 & 新手続き形式 & 条 & $\begin{array}{l}\text { 現行手続き形式 } \\
\text { (理事会は全会一致) }\end{array}$ \\
\hline 62 条 2 項(a) & 域外国境における検問 & 共同決定手続き & $\begin{array}{l}\text { 加盟国の域外国境を人 } \\
\text { 加過すること関す } \\
\text { る措の範囲について } \\
\text { の協定の合意後 } * 2\end{array}$ & 諮問手続き*1 \\
\hline 62 項 3 項 & 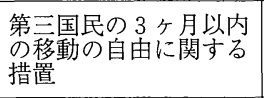 & 共同決定手続き & 2004 年 5 月 1 日より ${ }^{* 3}$ & 諮問手続き*4 \\
\hline 63 条 1 項*5 & 亡命に関する措置 & 共同決定手続き & た共同体法 & 諮問手続き*7 \\
\hline 63 条 2 項 $(a)^{* 8}$ & $\begin{array}{l}\text { 難民等に対する一時的 } \\
\text { 保護 }\end{array}$ & 共同決定手続き & $\begin{array}{l}\text { 大枠を定めた共同体法 } \\
\text { 採択後*9 }\end{array}$ & 諮問手続き*10 \\
\hline 63 条 3 項 $(b)$ & 不法移民及び不法滞在 & 共同決定手続き & 2004 年 5 月 1 日より*11 & 諮問手続き*12 \\
\hline 66条 & $\begin{array}{l}\text { IV 編の分野における } \\
\text { 行政的協力 }\end{array}$ & 諮問手続き & 2004 年 5 月 1 日より & 諮問手続き*14 \\
\hline 67 条 & $\begin{array}{l}\text { 第 IV 部全体に対する } \\
\text { 共同決定手続きの適用 } \\
\text { 範囲の拡大に関する規 } \\
\text { 定 }\end{array}$ & 共同決定手続き & $\begin{array}{l}\text { 2004年5月1日もしく } \\
\text { はそれ以降できるたた } \\
\text { 速やかに*16 }\end{array}$ & 諮問手続き*17 \\
\hline 137 条 2 項 & 社会規定の一部 & 共同決定手続き & $\begin{array}{l}\text { 理事会の全会一致を必 } \\
\text { 要とる瓷手続きに } \\
\text { より手続きを変更 }\end{array}$ & 諮問手続き*17 \\
\hline 161 条*18 & $\begin{array}{l}\text { 構造基金及び結束基金 } \\
\text { に関する規定 }\end{array}$ & 同意手続き*19 & 2007 年 1 月 1 日より & 同意手続き*21 \\
\hline 279 条 1 項 & $\begin{array}{l}\text { 財政規則及び会計官等 } \\
\text { 関す規則 }\end{array}$ & 諮問手続き*22 & 2007年 1 月 1 日より & 諮問手続き $* 23$ \\
\hline
\end{tabular}

* 1，4，7，10，12，14 加盟国による発議も可能

* 2, 3，11，16 欧州共同体設立条約 67 条に関する宣言

$* 5,8$ 手続きは, $\mathrm{EC}$ 設立条約 67 条 5 項で規定

* 6，-9 理事会の全会一致を必要とする諮問手続き（加盟国による発議を含む）により制定

*13 欧州共同体設立条約 67 条に関する議定書

*15 理事会の全会一致を必要とする諮問手続き（加盟国による発議を含む）など。

* 17, 21 経済社会委員会及び地域委員会への諮問を必要とする。

*18 欧州共同体設立条約161条に関するギリシャ，スペイン及びポルトガルによる宣言及び欧州共

同体設立条約161条に関するデンマーク，ドイツ，オランダ及びオーストリアによる宣言を参照。

*19 経済社会委員会及び地域委員会への諮問が必要, 理事会は, 特定多数決で行為する。

*20 2007年 1 月 1 日までに，2007年 1 月 1 日より適用される多年次財政見通し及びそれに関連する

機関間合意が採択された場合。それ以外の場合には，上記の多年次財政見通し及びそれに関連す

る機関間合意が採択された日から適用される。

$* 22,23$ 会計検査院の意見を必要とする。 
『日本 $\mathrm{EU}$ 学会年報』第 22 号, 平成14年 9 月

(1) EU 条約に関する改定

EU 条約に関する改定では，まず，7条 1 項が新たに規定されたことにより， EUが掲げる原則に関する加盟国による重大な違反が生じる危険に対する勧告 を行う手続きに関しては，欧州議会が同意手続きを通じて関与することが可能 となっている。また，理事会での決定に4/5の多数決制度が導入されたことに よって，この規定の実施可能性が高められているといえよう。 $27 \mathrm{c}$ 条及び $27 \mathrm{e}$ 条に関しては，より緊密な協力方式を共通外交・安全保障政策の領域に新たに 導入した結果として特定多数決制が導入されている。国際協定締結に関する規 定を含む 24 条 3 項及び 4 項に関しては，全会一致により行われる域内措置を必 要とする協定の場合には，理事会では全会一致が，特定多数決によって行われ る統一行動及び共通の立場の採択あるいは域内の措置を協定が含む場合には， 特定多数決が行われると規定することによって，EUが締結する国際協定とそ れに含まれる EUの域内措置等の政策決定の整合化（内外権限並行主義）が行わ れている。

（2） $\mathrm{EC}$ 条約（共同体の政策）に関する改定

欧州議会の権限に関しては，11条が改定され，より緊密な協力が共同決定手 続きを適用される分野に関連する場合には，欧州議会が同意手続きによって参 加することが可能となっている（権限並行主義による手続き間の整合化）。

理事会における特定多数決の適用範囲の拡大に関しては，100条 1 項などの 4 条項に関しては，いずれも非諮問手続きのままであるが，理事会の決定方式 が全会一致から特定多数決に変更されている。ただし，123条 4 項に関しては， ユーロ参加国のみによる特殊な特定多数決方式である。また，新規規定である 133 条 5 項には理事会による特定多数決が導入され，同じく $181 \mathrm{a}$ 条に関しては 理事会の特定多数決による諮問手続きが導入されている。

共同決定手続きに関しては，ニース条約の発効と同時に，5つの分野におい て共同決定手続きが新たに導入される予定である。たたし，18条 2 項に関して は，現行条約では，共同決定手続き過程における理事会の決定を全て全会一致 
で行うこととするこれまでの条件を削除し，通常の共同決定手続きとしたもの である。

（3）機関の構成員の任命及び手続き規則に関する改定

今回の改定では，決定の遅延が許されない $\mathrm{EU}$ 諸機関の構成員の任命ある いは各機関の手続き規則の承認などについての理事会の採決を全会一致から特 定多数決に変更したことが特徴の 1 つとして上げられる。これらは今回の改定 による政策決定手続きの変更の中で，全体の約 $1 / 3$ 近くを占めている。

（4）ニース条約発効後，適用期日及び条件付きで新しい手続きが導入される 条項

今回の改定では, 保留あるいは, 先送りされた条項が非常に多いのが特徴で ある。ニース条約発効と同時に新たに共同決定手続きが適用される項目が 5 項 目にすぎないのに対して，留保された項目は 7 項目にものぼる。

留保された条項の決定手続きの移行条件には，大きく分けて期日を明確に設 定したものと一定条件の達成を条件としたものの 2 種類がある。ただし，期日 を明記した条項の内でも，67条は，例外的に期日以降の共同決定手続きの導入 も認めるものとなっている。

理事会における特定多数決及び共同決定手続きなどの適用範囲の拡大は，一 見多くの項目に及んでいるようにも見えるが，多くの部分を諸機関の構成員の 任命あるいは手続き規則の承認に関する項目が占めるために，政策分野に関し ては，依然として限定的である。政策決定に関する改定に関しては，理事会で の全会一致が求められる分野が依然として多く存在しており（税制，社会保障， 通商政策など)，共同決定手続きの大幅な一括導入も今回は見送られたのである。

\section{おわりに}

ニース条約に付属する「同盟の将来に関する宣言」では，「ニース条約の批 准をもって，EUが新しい加盟国の加盟のために必要な組織的改革を完了する 
『日本 $\mathrm{EU}$ 学会年報』第 22 号, 平成14年 9 月

ことを強調する」と述べられている。しかしながら，本当に今回の改定によっ て EUの組織的改革は完了したのであろうか。

今回の改定で, 最も大きな課題となったのは, アムステルダム条約の際に合 意できなかった組織改革，特に理事会での決定方式及び欧州委員会の定員の問 題である。どちらの問題も EUにおける加盟国の影響力の増減に直結する問 題であり，EUの政策決定過程に関わる欧州議会の議席配分も含女て，EUに おける各加盟国の影響力を反映する重要な要素である。そのため，これら 3 機 関に代表される加盟国の数字，すなわち欧州議会の議席数，理事会における加 重票数と特定多数決のための要件及び欧州委員会の委員数が互いにリンクする ことになり，ニース条約の改定交渉は，加盟国間での数字の駆け引きとなり， $\mathrm{EU}$ の全体的な機構あるいは政策決定の改革ではなく，加盟国間の単なる数字 の分捕り合戦に終わってしまっている感は拭えない。

やや極端で単純な原則論ではあるが，そもそも加盟国民の声を直接反映する ために直接選挙で選出される欧州議会，加盟国の国益を擁護する理事会，そし て EU 全体の利益を代表する欧州委員会というそれぞれの特徴を考えあわせ れば，小国であっても主権国家としての立場に配慮するために加盟国の人口比 を十分には反映できない欧州議会，主権国家間の平等原則と加盟国の人口とい う両立不可能な $2 つ 0$ 側面を中途半端な形で反映する加重票数によって特定多 数決を行おうとする理事会，出身加盟国の国籍を最重要の基準として選出され る欧州委員会という現況は，ニース条約による改定あるいは改定を巡る論議の 中でますます鮮明になってきた問題点である。今回の改定でもこの矛盾がほと んど改善されなかったのは，それぞれの機関がいかなる利益を代表し，またそ の利益を代表するためには，いかなる構成員あるいは決定手続きが必要なのか を明確化せずに，目の前の駆け引きに終始した結果であるともいえよう。

さらにいえば，現在の制度は，EECが設立されて以来，今日までの EUの 拡大によってもほとんど根本的な改革なしに，維持されてきたものである。そ のため，50年前に 6 力国からなる EEC のために用意された制度を現在の15力 
国あるいは，将来的には27カ国からなる $\mathrm{EU}$ が利用し続けようとしているこ とに制度的問題が蓄積される根本的原因があるように思われる。

いずれにせよ，ニース条約による機構改革は現行制度の範囲内での改良には ある程度成功しているともいえるかもしれないが, 現在の政策決定メカニズム あるいは機関の権限関係の範疇で改善できるものには自ずと限界があることも 事実である。今後，全体の権限関係の見直しが必要とされることになるであろ う。EUは，現行の制度の枠内での数字あわせの改善ではなく，根本的な真の 改革が必要な時期に来ているように思われる。

〔追記〕 本稿は，2001年の11月17日の長崎純心大学での日本 EU 学会での報告をも とに，加筆修正したものである。諸先生から頂いた質問やコメントに感謝申し上げる とともに，特に貴重な助言を頂いた中村民雄教授（東京大学）には記して改めて謝意 を申し上げたい。

1) ニース条約は, アムステルダム条約等と同じく, EU 条約, EC 条約, EAEC 条約及び ECSC 条約とそれらに付属する議定書等を改定する条約である。なお, 条約の内容について は, “Treaty of Nice amending the Treaty on European Union, the Treaties establishing the European Communities and certain related Acts", Offcial Journal of European Communities 2001/C 80, 10.3. 2001 及び鷲江義勝, 久門宏子, 山内麻貴子, 山本直「ニース条約の翻訳(1), (2)」同志社法学 278 号及び279号，2001年を参照されたい。

2 ) ニース条約のための政府間会議の主な目的は, 欧州委員会の規模と構成, 理事会の加重票数 の見直し，理事会の特定多数決の使用領域の拡大およびより緊密な協力に関する規定の見直し などであった。The European Commission, "Intergovernmental Conference Factsheets After the Treaty of Nice”, p.1,アムステルダム条約の「欧州同盟の拡大を想定した機関に関する議 定書」及び「欧州同盟の拡大を想定した機関に関する議定書についてのベルギー, フランス及 びイタリアによる宣言」。

3 ）例えば, フランスでは, 6月12日に下院（賛成407, 反対 27 , 棄権103）で, 29 日には上院 （賛成288, 反対8, 棄権30）でニース条約の批准を完了している。

4） 2001 年 6 月 7 日のアイルランドで行われた国民投票では，ニース条約の批准が否決されたた め（投票率 $34.8 \%$ ，賛成 $46.1 \%$ ，反対 $53.9 \%)$ ，ニース条約の発効自体が賏念されていたが， イェーテボリ欧州理事会では，ニース条約の再交渉はせず，アイルランドで国民投票を再度実 
『日本 $\mathrm{EU}$ 学会年報』第 22 号, 平成14年 9 月

施することなど，アイルランドの国民投票の結果は，今後のニース条約批准プロセスや拡大交 渉に影響を及ぼさないことが確認されている。外務省 http ://www. mofa. go. jp/mofaj/area/ eu/eu-010617. html.

5 ） ニース条約による改革の全般については, 庄司克宏,「ニース条約（EU）の概要と評価」, 横浜国際経済法学，第10巻第 1 号，2001年 7 月，中村民雄，「ニース条約による EC の機構改 革」，貿易と関税，2001年 8 月号，䉆江義勝，久門宏子，山内麻貴子，山本直「「ニース条約に よる欧州同盟（EU）条約および欧州共同体（EC）設立条約の改定に関する考察(1)，(2)」，同 志社法学278号及び279号, 2001年, Kieran St C Bradley, “Institutional Design in the Treaty of Nice", Common Market Law Review No.38, 2001, Richard E Baldwin, Erik Berglof, Francesco Givazzi and Mika Widgren, Nice Treaty:Should the treaty of Nice be Ratified?, Centre for Economic Policy Research, 2001 を参照されたい。

6 ) The European Commission, "Intergovernmental Conference Factsheets European Parliament", p. 2.

7 ）アムステルダム条約 2 条37項。な扔，アムステルダム条約に関しては，金丸輝男編著『EU アムステルダム条約 - 自由・安全・公正な社会をめざして一」, 日本貿易振興会，2000年を参 照されたい。

8 ）欧州議会に関するその他の改革としては, 欧州政党への資金援助 (EC 条約191条), 司法裁判 所への提訴権 (EC 条約 230 条) 及び審査請求権 (EC 条約 300 条 6 項) の獲得などが挙げられる。

9 ）加重投票数の配分をめぐる対立に関しては, 例えば, Xenophon A. Yataganas, “The Treaty of Nice The Sharing of Power and the Institutional Balance in the European Union-A Continental Perspective", Harvard Jean Monnet Working Paper 01/01, Harvard Law School, p. 41. を参照されたい。

10) The European Commission, "Intergovernmental Conference Factsheets Weighting of Votes” p. 2 及びXenophon A. Yataganas, op, cit, p. 41.

11）これは, 中小の10加盟国によって支持された。Xenophon A. Yataganas, Ibid.なお, 現在ま での特定多数決の場合には, 可決に必要な賛成票数を構成する加盟国数は, 常に過半数を超え ているため, 改めて明記する必要性はなかったのである。

12）例えば，欧州委員会が提出した意見書の中では，加重投票数の再配分による現行の特定多数

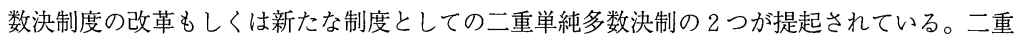
単純多数決制度とは，1）加盟国の過半数の賛成及び 2 ）賛成した加盟国の人口の総和が $\mathrm{EU}$ の総人口の過半数を占めるという $2 つ の$ 条件を満たした場合, 可決できるとするものである。 Commission, "Commission Opinion in Accordance with Article 48 of the Treaty on European Union on the calling of a Conference of Representatives of the Governments of the Member States to amend the Treaties", COM (2000) 34, 26 January 2000, pp. 30-32.

13) Commission of European Coomunities Secretary-General, "Memorandum to The Members of The Commission", Brussels, SEC (2001) 99, January 18, 2001, p. 3.

14）ただし，この要件は，加盟国が，この要件を満たしているかどうかの確認を要求した場合に のみ必要となる（「欧州同盟の拡大に関する議定書」 3 条及び「欧州同盟の拡大に関する宣 
言」)。

15）これは，EUの15力国への拡大の際の票数改定に当たって，大国の影響力を確保するために 導入された「イオニアの妥協」とある意味同じような効果を持つ要件である。「イオニアの妥 協」は, 第 4 次拡大交渉の中で, イギリスとスペインの強硬な主張によって, 反対票が阻止少 数を满たさない場合でも，23から 25 票の場合には，「合理的期間」審議を継続して妥協を模索 するとの合意である。しかし，票数のみを基準とする「イオニアの妥協」は同じ票数を持つ大 国に平等な影響力の確保を保証するものであるのに対して，人口要件は，人口による影響力の 格差を認めるため, 大国間にも影響力の差をもたらすことになる。なお，イオニアの妥協に関 しては，田中俊郎『EUの政治」，岩波書店，1998.3，43頁を参照。

16) Agence Europe 12/12/2000.

17）例えば，より緊密なる協力の発動には，特定多数決による決定が必要とされるが，一端発動 されたより緊密な協力の領域における 8 力国程度の加盟国による特定多数決方式による政策決 定の方が27カ国による特定多数決より遙かに容易であるともいえよう。

18）欧州委員会のこれまでの改革については，ニース条約による改革を含めて福田耕治「欧州委 員会に扔ける行政改革一アムステルダム条約からニース条約へ向かって一」ワールドワイドビ ジネスレビュー2巻 2 号，2001年に詳しく分析されている。

19）国家元首または政府首脳によって構成される理事会（EC 条約214条 2 項）。

20）中村民雄，前掲論文，75頁。

21) Commission of European Comunities Secretary-General, "Memorandum to The Members of The Commission", Brussels, SEC (2001) 99, January 18, 2001, p. 4.

22）この 217 条 1 項の第 1 文（欧州委員会は委員長の政治的指針の下に活動する）は, 219 条 1 段 より移動された条文である。

23) Xenophon A. Yataganas, op,cit, p. 43.

24）アムステルダム条約に付属する「欧州同盟の拡大を想定した機関に関する議定書」 1 条「同 盟の最初の拡大が発効する日に，EC 条約213条(1)，ECSC 条約 9 条(1)， EAEC 条約126条(1)に かかわらず，あらゆる関連する要素，特に委員会の 2 人目の委員を指名する可能性を断念する 加盟国への補償を考慮に入れつつ，すべての加盟国に受け入れられる方法で，その日までに理 事会の投票の割合が票数の再配分もしくは二重多数決のどちらかによって，变更されることを 条件に，委員会は，各加盟国の 1 人の国民を構成員とする。」

25）この輪番制は，大国と中小国の対立の中から生まれたまさに妥協の産物である。Xenophon A. Yataganas, op, cit, p. 42.

26）現状では，27カ国の EU 体制となるのは，2005年以降であり，そのため，この輪番制が実 際に適用されるとしても2010年に任命される欧州委員会に関してである。

27）特定多数決の適用範囲をの拡大をめぐる加盟各国の主張については, 槩江義勝, 久門宏子, 山内麻貴子，山本直，前揭論文，17-18頁を参照されたい。

28）この原則は全ての面で，一貫しているわけではなく，欧州議会の権限に関しては，必ずしも この原則が適用されてはいない。な扔，内外権限並行主義については，庄司克宏，前掲論文， 40-44頁を参照。 


\section{Reforms of the Main Institutions and Decision-making of the European Union}

\section{Yoshikatsu Washie}

In December 2000, the Nice European Council agreed on a new treaty for the EU : the Treaty of Nice. The treaty was signed in February 2001 and is in the process of being ratified by the 15 member states of the EU. The treaty concerns institutional adaptation of the EU for enlargement within a few years.

This article analyze the reforms in the Treaty of Nice, in particular, the European Parliament, the Council of Ministers, the European Commission, and the decision-making system of the EU.

1) The European Parliament

The number of MEPs (Member of the European Parliament) of existing member states will be reduced at next election of the European Parliament in 2004. 302 seats are to be allocated to new member states.

2) The Council of Ministers

The treaty re-allocates the voting strength of individual existing member states and new member states in the Council of Ministers. Two qualified majority thresholds are to be introduced. The new qualified majority requires assent of at least $62 \%$ of the total population of the $\mathrm{EU}$ and a majority of the members.

3 ) The European Commission

The Treaty of Nice amends the appointment procedure of the Commission. The nominee President is to be chosen by the Council (composed of Heads of State or Government) by a qualified majority. The list of other 
members of the Commission is to be adopted by the nominee-President and the Council, acting by a qualified majority. The Commission is to be appointed by the Council by a qualified majority.

The composition of the Commission is also to be amended. If there are fewer than 27 member states, the composition of the new Commission from 2005 will have the same number of member states. When the EU consists of 27 member states, the number in the Commission is to be less than the number of member states. Membership in the Commission will be by rotation.

The treaty of Nice also reinforces the powers of the Commission President by amending article. 217.

\section{4) Decision-making}

The qualified majority voting of the Council and the co-decision procedure are to be extended to new areas. But those areas needing the unanimity of the Council still remain.

This Treaty represents the largest possible modification within the existing EU framework. However, the $\mathrm{EU}$ also is in need of fundamental institutional reform. 